\title{
Bone metabolism in rheumatoid arthritis compared with postmenopausal osteoporosis
}

\author{
R M VAN SOESBERGEN, ${ }^{1}$ P LIPS, ${ }^{2}$ A VAN DEN ENDE, ${ }^{3}$ AND \\ J K VAN DER KORST
}

From the ${ }^{I}$ Department of Rheumatology, Slotervaartziekenhuis and Jan van Breemen Institute, Centre for Rheumatology and Rehabilitation, Amsterdam, The Netherlands; the ${ }^{2}$ Department of Internal Medicine, Academisch Ziekenhuis der Vrije Universiteit, Amsterdam; and the ${ }^{3}$ Department of Clinical Biochemistry, Slotervaartziekenhuis, Amsterdam

SUMmARY Calcium and bone metabolism in 29 rheumatoid arthritis (RA) patients were compared with those in 27 postmenopausal osteoporotic patients. Signs of vitamin D deficiency were found in $20 \mathrm{RA}$ patients, including 12 who took recommended amounts of vitamin D in their diets and were exposed to sufficient sunlight, and in none of the osteoporotic patients. There were no signs of malabsorption. In six out of 15 patients we found increased liver enzyme activity, which may have a role in vitamin $\mathrm{D}$ metabolism. We propose the influence of non-steroidal anti-inflammatory drugs (NSAIDs) on vitamin D metabolism in the liver as a possible explanation.

Key words: vitamin D metabolism, vitamin D deficiency, secondary hyperparathyroidism, calcium metabolism, liver enzyme induction, non-steroidal anti-inflammatory drugs.

Osteopenia is a common feature of rheumatoid arthritis (RA). In several studies ${ }^{1-5}$ RA patients have shown decreased bone calcium content and bone density compared with those of matched controls. No difference was found between male and female RA patients.

Several investigators have suggested an underlying disturbance in calcium and vitamin D metabolism as a cause of the osteopenia of RA. Most laboratory evidence for vitamin $D$ deficiency is derived from studies carried out in Great Britain. ${ }^{6-8}$ Vitamin $\mathrm{D}$ is a legally obligatory additive to margarine in the Netherlands. A study of vitamin D metabolism among Dutch RA patients was therefore warranted.

This communication reports the results of our study of bone metabolism in RA patients and postmenopausal osteoporotic controls. The interaction between the regulation of calcium metabolism by vitamin $\mathrm{D}$ and by parathyroid hormone is studied in more detail.

Accepted for publication 18 June 1985

Correspondence to $\operatorname{Dr} R \mathrm{M}$ van Soesbergen, Department of Rheumatology. Slotervaartziekenhuis, Louwesweg 6, 1066 EC Amsterdam, The Netherlands.

\section{Patients and methods}

PAT I E N TS

Twenty nine patients, four male and 25 female, with longstanding definite or classical RA were compared with 27 osteoporotic postmenopausal (OP) women. Twenty of the RA patients were seropositive. The diagnostic criteria for OP were radiologic osteopenia, accentuation of the upper and lower margins and vertical trabeculae of the vertebrae (all patients), collapsed vertebrae (18 patients) or other fractures (four patients), or back pain. Other causes of osteopenia were excluded. Patients taking anticonvulsant drugs and those with known liver, kidney, endocrine, or gastrointestinal disorders were excluded from both groups.

\section{METHODS}

Serum parameters were obtained after overnight fasting. Analysis was made of serum calcium, inorganic phosphate, total protein, albumin, creatinine, $\gamma$-glutamyltranspeptidase activity, alkaline phosphatase activity, vitamin $\mathrm{E}$, folic acid, gastrin, and urinary calcium, creatinine, phosphate, and hydroxyproline. Faeces were collected over a 
72-hour period and weighed. If this weight exceeded $500 \mathrm{~g}$ faecal fat content was estimated.

Maximal tubular phosphate reabsorption (Tm$\mathrm{PO}_{4} / \mathrm{GFR}$ ) was calculated by the method of Walton, ${ }^{9}$ and Payne's formula ${ }^{10}$ was employed to correct serum calcium concentration for albumin concentration. Values are presented as mean $\pm S D$ unless stated differently.

Serum parathyroid hormone levels (PTH levels) were determined by a radioimmunoassay specific for the C-terminal region. The serum concentration of 25-hydroxyvitamin D $(25(\mathrm{OH}) \mathrm{D})$ was measured by a competitive protein binding assay in two different laboratories with nearly identical reference values. The serum level of 1,25-dihydroxyvitamin D $\left(1,25(\mathrm{OH})_{2} \mathrm{D}\right)$ was determined by a competitive protein binding assay after purification by highperformance liquid chromatography. ${ }^{11}$ The serum total bile acids after fasting and two hours after loading with chenodeoxycholic acid $(1 \mathrm{~g})$ were estimated by an enzymatic spectrophotometric method with $3 \alpha$-hydroxysteroid dehydrogenase. ${ }^{12} 13$ The hydroxylation pattern of the bile acids was determined by a thin-layer chromatographic method. ${ }^{14}$ A D-xylose loading test was performed with $25 \mathrm{~g}$ D-xylose according to Richterich et al. ${ }^{15}$ Urinary glucaric acid concentration was determined before and after loading with D-glucuronolactone (1 g) according to Marsh. ${ }^{16}$

$X$-ray photographs of the pelvis and the thoracic and lumbar spine were performed. Statistical analysis was performed with the two-tailed Student's $t$ test $(p<0.05)$. Vertical iliac crest biopsy specimens were obtained after double tetracycline labelling and were processed without decalcification. Biopsy specimens obtained from 22 OP patients were evaluated qualitatively. The biopsy specimens from 17 RA patients were quantitatively analysed by histomorphometric methods. ${ }^{17}$ The following parameters were measured in trabecular bone: $(a)$ trabecular bone volume (TBV), i.e., the volume occupied by trabecular bone and osteoid tissue, expressed as a percentage of the total volume between the cortices, $(b)$ osteoid volume $(\mathrm{OV})$, i.e., the volume of osteoid tissue, expressed as a percentage of trabecular bone volume, $(c)$ osteoid surface (OS), i.e., the trabecular surface covered by osteoid seams, expressed as a percentage of total trabecular surface, $(d)$ thickness index of osteoid seams (OV/ OS), i.e., an estimation of osteoid thickness calculated as $100 \times \mathrm{OV} / \mathrm{OS},(e)$ resorption surface $(\mathrm{RS})$, i.e., the trabecular surface occupied by resorption lacunae with or without osteoclasts, expressed as a percentage of total trabecular surface, $(f)$ mineralisation rate $(\mathrm{M})$, i.e., the mean distance between double tetracycline labels (each pair measured on equidistant points) divided by the labelling interval expressed as $\mu \mathrm{m} /$ day.

The results of the histomorphometric measurements were compared with results for controls of similar age and sex from the literature. ${ }^{18-20}$

Daily protein, calcium, phosphate, and vitamin D intake were recorded by a dietician. Questionnaires were completed for average sunlight exposure and for mobility. The results are given in Table 1 .

\section{Results}

Disease activity of RA was moderate or severe. The duration ranged from five to 31 years (mean 15.8 years). Eight RA patients were in the Steinbrocker functional capacity grade II, five in II to III, 15 in III, and one in III to IV. Twenty four of the OP patients were in grade II and three in II to III. The ages of the RA patients ranged from 52 to 74 years (mean 64 years), and the ages of the OP patients from 52 to 71 years (mean 69 years). Disease complications in the RA patients were Sjögren's syndrome (14), vasculitis with polyneuropathy (three), Felty's syndrome (two), and cervical myelum compression (two). Eleven had no disease $\vec{\bullet}$ complications.

Eighteen of the 27 OP patients had collapse vertebrae as compared with five of the $29 \mathrm{R} \overline{\mathrm{A}}$ patients. The $x$-rays of all OP and 25 RA patients showed osteopenia. Whereas only one OP patient had a low serum calcium level, 23 RA patients had serum calcium levels below $2.25 \mathrm{mmol} / \mathrm{l}$ (reference value $2 \cdot 25-2 \cdot 60 \mathrm{mmol} / \mathrm{l}$ ). Disease activity was reflected in low serum albumin levels in 21 of the RA patients. Serum calcium levels were corrected for

Table 1 Comparison of predisposing factors in the osteoporotic (OP) and rheumatoid (RA) groups

\begin{tabular}{lcc}
\hline Predisposing factor & $O P$ & $R A$ \\
\hline Mobility (walking) & - & 4 \\
$0-10 \mathrm{~m}$ & 2 & 25 \\
$10-100 \mathrm{~m}$ & 25 & \\
$100 \mathrm{~m}$ or more & - & 16 \\
Sunlight exposure (h/day) & 3 & 8 \\
0 & 24 & 5 \\
$0-1$ & & 17 \\
1 or more & - & 12 \\
Vitamin D (IU/day) in diet & 27 & 12 \\
$0-100$ & 5 & 17 \\
100 or more & 22 & \\
Calcium (mg/day) in diet & & \\
$0-800$ & & \\
800 or more & & \\
\hline
\end{tabular}


albumin. There was no difference between RA and OP patients in serum calcium corrected for albumin, in serum creatinine, or in inorganic phosphate.

In $17 \mathrm{RA}$ patients serum alkaline phosphatase activity was increased as shown in Table 2 . In contrast with OP patients, in whom $24 \mathrm{~h}$ urinary calcium and hydroxyproline excretion were found within the reference range, $22 \mathrm{RA}$ patients had a markedly decreased excretion of calcium ( 1.9 versus $3.9 \mathrm{mmol} / 24 \mathrm{~h})$ and increased hydroxyproline excretion (33 versus $19 \mathrm{mg} / 24 \mathrm{~h}$ ), suggesting vitamin D deficiency. This was confirmed by serum $25(\mathrm{OH}) \mathrm{D}$ levels in the RA patients. These were below normal with a mean value of $23.8 \mathrm{nmol} / \mathrm{l}$. The $\mathrm{PTH}$ levels in 14 patients were increased, suggesting secondary hyperparathyroidism. The mean PTH concentration for $27 \mathrm{RA}$ patients was $332 \mathrm{pg} / \mathrm{ml}$; the mean value obtained in 10 OP patients was $203 \mathrm{pg} / \mathrm{ml}$ (see Figs 1 and 2).

Vitamin D intake and sunlight exposure were deficient in 17 RA patients; the remaining 12 patients, whose dietary intake of vitamin $D$ was adequate and who had sufficient sunlight exposure, also had low $25(\mathrm{OH}) \mathrm{D}$ levels.

None of the patients showed signs of malabsorption. In 15 RA patients the excretion of glucaric acid was measured before and after oral loading with D-glucuronolactone; in six instances the results indicated liver enzyme induction (Fig. 3).

Bile acid determinations did not show any liver dysfunction. The hydroxylation pattern of the bile acids (not dependent on cytochrome $\mathrm{P}_{450}$ ) did not differ significantly from results obtained in a reference population.

Table 2 Comparison of biochemical values in the osteoporotic (OP) and rheumatoid (RA) groups

\begin{tabular}{|c|c|c|c|}
\hline Results & Reference value & $O P$ & $R A$ \\
\hline $\mathrm{S} .^{*}$ calcium $(\mathrm{mmol} / \mathrm{l})$ & $2 \cdot 25-2 \cdot 60$ & $2 \cdot 38 \pm 0 \cdot 02$ & $\doteqdot 2 \cdot 17 \pm 0 \cdot 02$ \\
\hline S. albumin $(g / l)$ & $41-45$ & $43 \cdot 4 \pm 0 \cdot 02$ & $\doteqdot 37 \cdot 0 \pm 0 \cdot 7$ \\
\hline S. calcium corrected $(\mathrm{mmol} / \mathrm{l})$ & & $2 \cdot 25 \pm 0 \cdot 03$ & $2 \cdot 29 \pm 0 \cdot 02$ \\
\hline S. alkaline phosphatase (IU/l) & $<110$ & $85 \pm 4$ & $\doteqdot 135 \pm 7$ \\
\hline S. creatinine $(\mu \mathrm{mol} / \mathrm{l})$ & $<120$ & $84 \pm 2$ & $74 \pm 3 \cdot 5$ \\
\hline S. inorganic phosphate $(\mathrm{mmol} / \mathrm{l})$ & $0 \cdot 6-1 \cdot 2$ & $1 \cdot 21 \pm 0 \cdot 03$ & $1 \cdot(07 \pm 0 \cdot 03$ \\
\hline U. ${ }^{*}$ calcium $(\mathrm{mmol} / 24 \mathrm{~h})$ & $4 \cdot 0-7 \cdot()$ & $3 \cdot 9 \pm 0 \cdot 3$ & $\div 1 \cdot 9 \pm 0 \cdot 3$ \\
\hline U. hydroxyproline $(\mathrm{mg} / 24 \mathrm{~h}) \dagger$ & $20-25$ & $19 \pm 1$ & $\ddagger 33 \pm 2$ \\
\hline $\mathrm{TmPO}_{4} / \mathrm{GFR}$ & $0 \cdot 80-1 \cdot 35$ & $1 \cdot 1 \pm 0 \cdot 1$ & $1 \cdot 03 \pm 0 \cdot 2$ \\
\hline S. $25(\mathrm{OH}) \mathrm{D}(\mathrm{nmol} / \mathrm{l})$ & 30 & $\left\{\begin{aligned} 76 \pm 6 & (n=8) \\
54 \pm 20 & (n=3)\end{aligned}\right.$ & $23 \cdot 8 \pm 2 \cdot 7 \quad(n=27)$ \\
\hline S. $1,25(\mathrm{OH})_{2} \mathrm{D}(\mathrm{pmol} / \mathrm{l})$ & $60-160$ & - & $87 \cdot 1 \pm 6 \cdot 9 \quad(n=9)$ \\
\hline S. РТH $(\mathrm{pg} / \mathrm{ml})$ & $80-270$ & $203 \pm 15 \quad(n=9)$ & $332 \pm 40 \quad(n=27)$ \\
\hline S. vitamin $E(\mu \mathrm{mol} / \mathrm{l})$ & $15-35$ & - & $21 \cdot 5 \pm 1 \cdot 7$ \\
\hline S. folic acid $(\mu \mathrm{g} / \mathrm{l})$ & $2-7$ & - & $4 \cdot 33 \pm 0 \cdot 46$ \\
\hline S. gastrin $(\mathrm{mg} / \mathrm{l})$ & $20-130$ & - & $90 \cdot 1 \pm 15 \cdot 5$ \\
\hline U. xylose $(g / 2 h)$ & 5 & - & $3 \cdot 83 \pm 0 \cdot 54$ \\
\hline Faeces weight $(\mathrm{g} / 72 \mathrm{~h})$ & 500 & - & $333 \cdot 7 \pm 46 \cdot 1$ \\
\hline S. bile acids fasting $(\mu \mathrm{mol} / \mathrm{l})$ & $6 \cdot 5$ & - & $3 \cdot 69 \pm 0 \cdot 86$ \\
\hline S. bile acids $2 \mathrm{~h}$ after loading & $14 \cdot 5$ & - & $11 \cdot 86 \pm 1 \cdot 76$ \\
\hline U. glucaric acid after loading ( $\%)$ & $11-21$ & - & $6 \cdot() \pm 2 \cdot 1$ \\
\hline
\end{tabular}

${ }^{*} \mathrm{~S}=$ serum; $\mathrm{U}=$ urinary

+ SI conversion: $\mathrm{mg} / 24 \mathrm{~h} \times 0.00763=\mathrm{mmol} / 24 \mathrm{~h}$

$\ddagger$ Significant by two-tailed Student's $t$ test $(p<0 \cdot(05)$.

All values are mean $\pm S E M$.

$-=$ not done.

Table 3 Histomorphometric data in patients with rheumatoid arthritis compared with control values from literature ${ }^{18-20}$

\begin{tabular}{|c|c|c|c|c|c|}
\hline & \multicolumn{2}{|c|}{ Control values } & \multicolumn{2}{|c|}{ Rheumatoid arthritis } & \multirow[t]{2}{*}{ Significance } \\
\hline & $n$ & $M e a n \pm S D$ & $n$ & Mean $\pm S D$ & \\
\hline TBV (\%) & 27 & $15 \cdot 0 \pm 3 \cdot 7$ & 15 & $13 \cdot() \pm 4 \cdot 4$ & NS \\
\hline OV (\%) & 42 & $2 \cdot 0 \pm 1 \cdot 2$ & 17 & $3 \cdot 4 \pm 2 \cdot 1$ & $\mathrm{p}<0 \cdot(0)$ \\
\hline OS $(\%)$ & 42 & $10 \cdot 7 \pm 6 \cdot 3$ & 17 & $24 \cdot 3 \pm 13 \cdot 6$ & $\mathrm{p}<0 \cdot(0) 1$ \\
\hline OV/OS & 42 & $18 \cdot 8 \pm 4 \cdot 7$ & 17 & $14 \cdot 3 \pm 4 \cdot 7$ & $\mathrm{p}<0.01$ \\
\hline RS (\%) & 130 & $3 \cdot 6 \pm 1 \cdot 1$ & 17 & $4 \cdot 2 \pm 2 \cdot 1$ & $0.05<p<0.10$ \\
\hline$M(\mu \mathrm{m} / \mathrm{d})$ & 11 & $0.73 \pm 0 \cdot 22$ & 15 & $(0 \cdot 66 \pm 0 \cdot 11$ & NS \\
\hline
\end{tabular}


Qualitative examination of bone biopsy specimens from the osteoporotic patients showed various degrees of osteopenia, with active remodelling in five and low grade remodelling in 17 samples.

In Table 3 and Fig. 4 the histomorphometric results in RA patients are compared with control values from literature. ${ }^{18-20}$

The RA patients had a lower TBV than controls $\frac{\bar{c}}{\omega}$. of similar age reported in the literature. However, $\overrightarrow{\vec{F}}$ the size of the group was small and the difference?

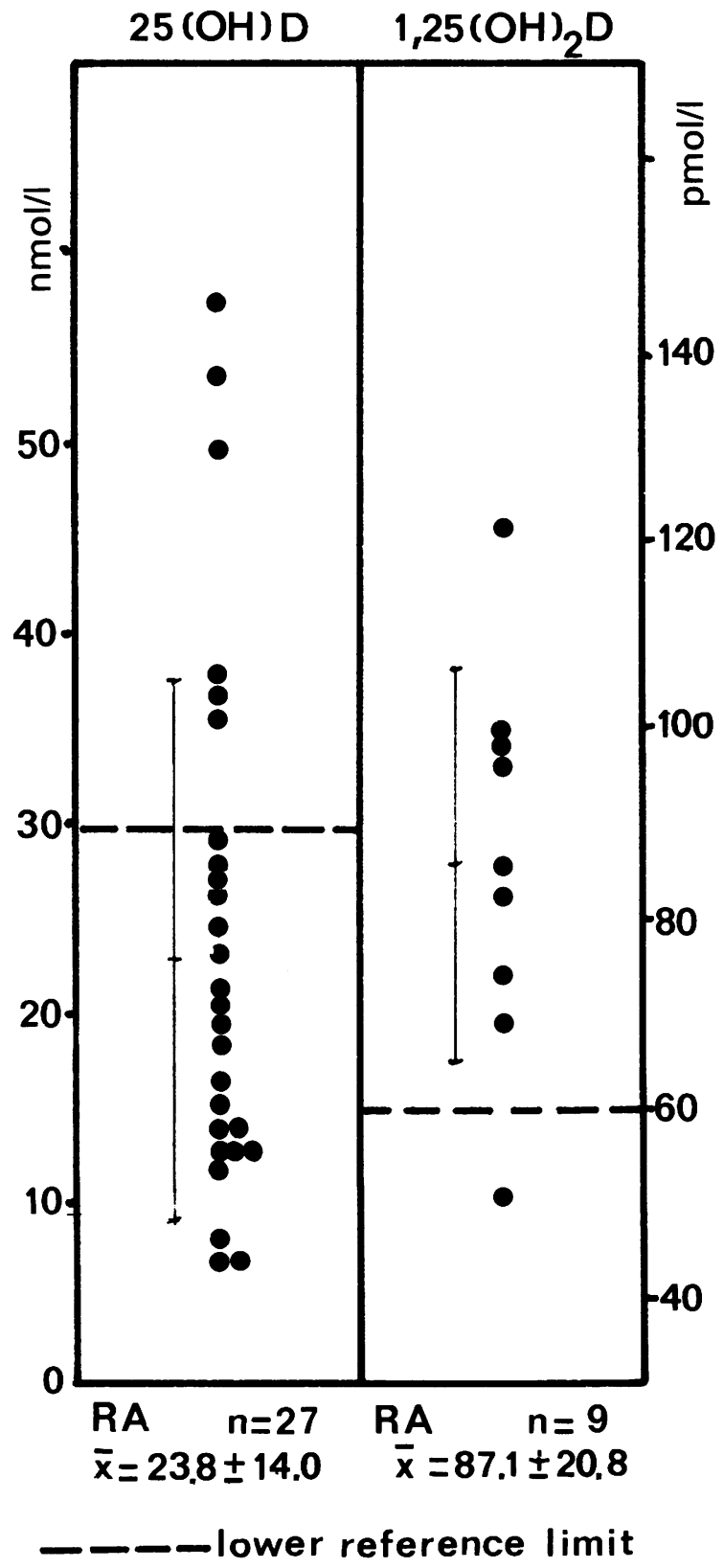

Fig. 1 Vitamin $D$ metabolites in patients with rheumatoid arthritis $(R A)$.
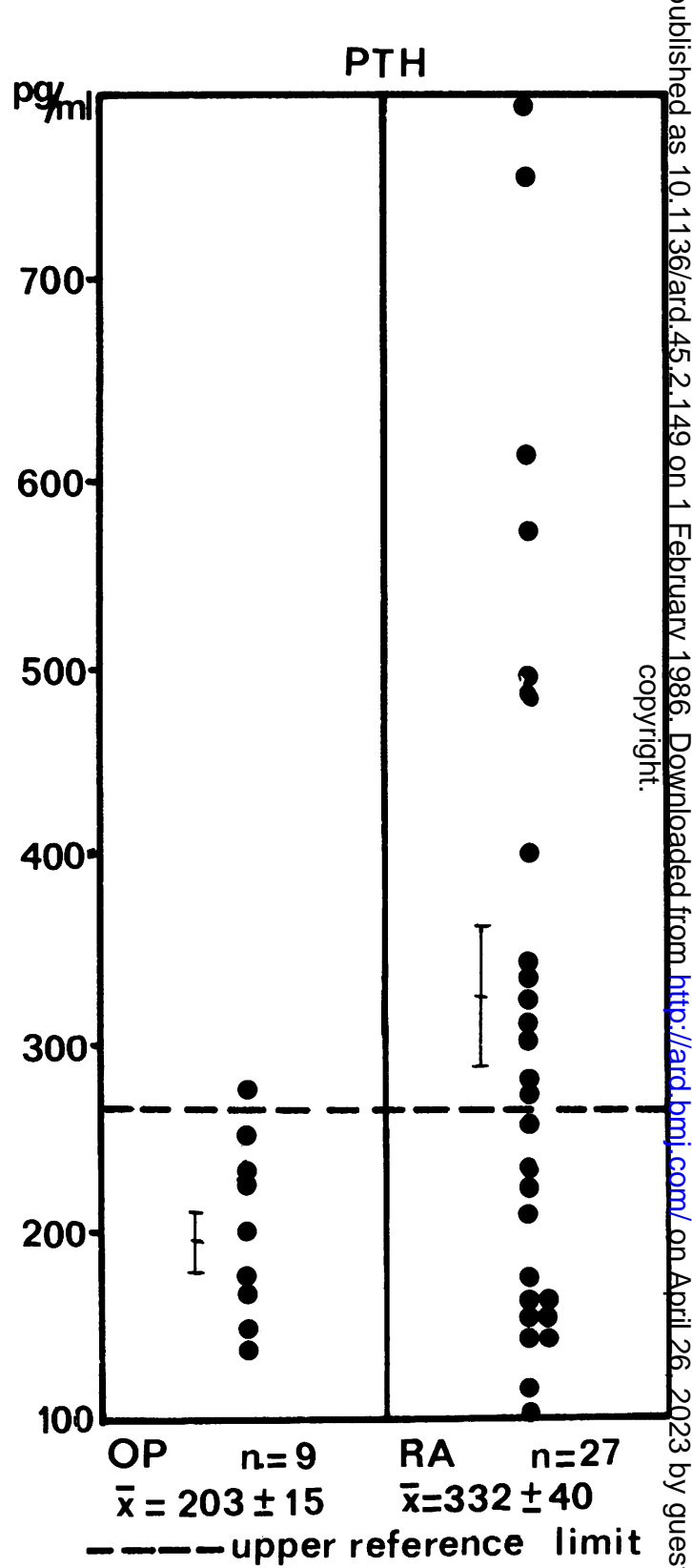

Fig. 2 Parathyroid hormone levels in osteoporotic (OP) and rheumatoid $(R A)$ patients. 
was not significant. A low TBV was observed in the two patients receiving corticosteroid treatment $(8.7$ and $8 \cdot 8 \%$ respectively).

The value of the remodelling parameters showed a wide variation. The osteoid volume was increased by more than $5 \%$ in three and the osteoid surface
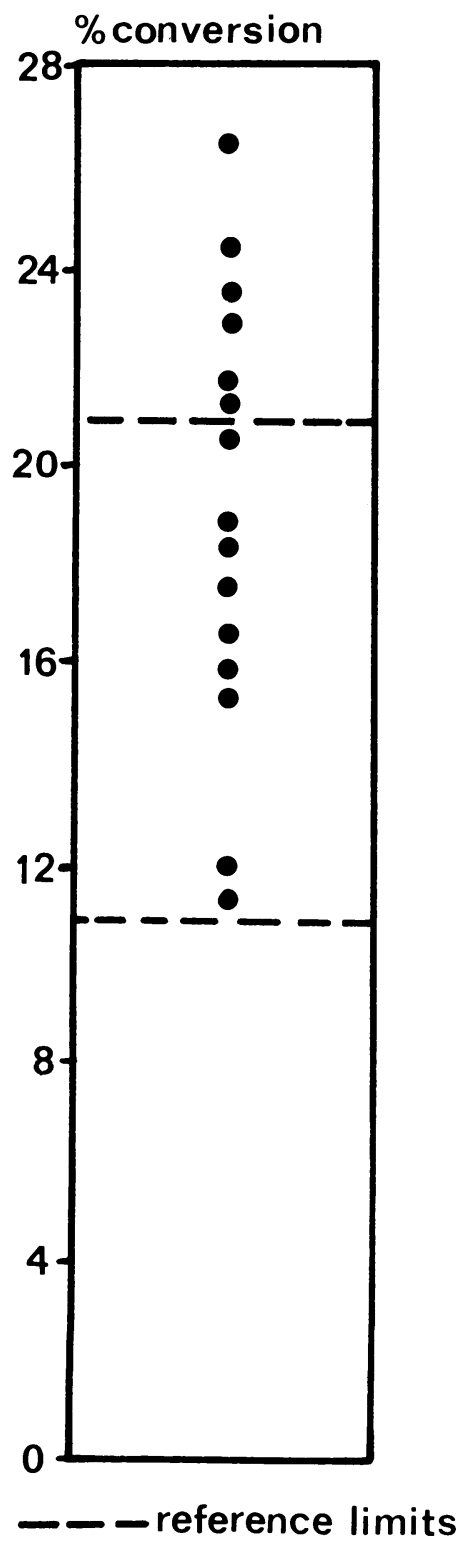

Fig. 3 Glucaric acid excretion after oral loading with $1 \mathrm{~g}$ D-glucuronolactone (expressed in \% conversion) in 15 rheumatoid $(R A)$ patients. was increased by more than $25 \%$ in eight biopsy specimens. However, no biopsy specimen showed an increase in the thickness of osteoid seams.

The mineralisation rate was normal in all biopsy specimens, so that mineralisation disturbance may be excluded. Five biopsy specimens showed evidence of high turnover, i.e., an increased resorption surface and extended osteoid surface.

\section{Discussion}

Signs of vitamin D deficiency were found in a large proportion of Dutch patients suffering from longstanding RA, in accordance with British studies. ${ }^{2-8}$ No vitamin $D$ deficiency was detected in a control group of primary osteoporotic patients. In most cases vitamin $\mathrm{D}$ deficiency was accompanied by secondary hyperparathyroidism, as shown by raised parathyroid hormone levels and signs of high turnover in the bone biopsy specimens. Vitamin D deficiency was shown both in RA patients with adequate dietary intake and sufficient sunlight exposure and in those for whom indications of insufficient dietary intake and low sunlight exposure were obtained. In none of the patients was malabsorption found. A disturbance of vitamin D metabolism may therefore be involved in RA. In pathological circumstances $1,25(\mathrm{OH})_{2} \mathrm{D}$ levels are maintained in the normal range as long as possible. There are no tests available for direct investigation of vitamin $\mathrm{D}$ metabolism in the liver. However, we did find indications of liver enzyme induction in six out of a total of 15 patients by an indirect test. Low $25(\mathrm{OH}) \mathrm{D}$ levels may be due to the influence of NSAIDs on vitamin D metabolism in the liver. It is possible that NSAIDs induce an increased enzymatic conversion of active vitamin D metabolites in the liver, as do anticonvulsant drugs. ${ }^{21}$ We are performing antipyrine loading tests in these patients in order to investigate further liver metabolic rate (hydroxylation activity dependent on cytochrome $\mathrm{P}_{450}$ ).

Histomorphometry of the bone biopsy specimens showed osteopenia both in the RA patients and in the primary osteoporotic patients. ${ }^{22}$ In $30 \%$ of the RA patients there was evidence of a high turnover. Increased bone turnover was also observed in RA patients with technetium bone scintigraphy. ${ }^{23-25}$ The high turnover is probably a manifestation of secondary hyperparathyroidism shown by the raised parathyroid hormone levels. Overt osteomalacia was excluded by the normal osteoid thickness index and the normal mineralisation rate in the bone biopsy specimens. ${ }^{17}$ It may be assumed that vitamin $\mathrm{D}$ deficiency, by decreasing calcium absorption and serum calcium levels, stimulates parathyroid hormone production to restore calcium levels. The 
secondary hyperparathyroidism stimulates renal calcium reabsorption, thus minimising urinary calcium loss.

The histological picture of high turnover agrees with that observed by others in incipient vitamin D deficiency. ${ }^{26}$ Only in later stages will true osteomalacia be found. The hyperparathyroidism may increase bone loss. ${ }^{17}$ Our results contrast with the findings in the recent study of $\mathrm{Ng}$ et al. ${ }^{27}$ These $\frac{2}{3}$ investigators observed no signs of osteomalacia or $\underline{\underline{n}}$. secondary hyperparathyroidism in RA bone biopsy specimens. The $25(\mathrm{OH}) \mathrm{D}$ levels were much higher $\overrightarrow{\vec{\rho}}$ in their patients than in ours. Only $9 \%$ of their patients had negligible sunlight exposure as opposed to $55 \%$ of the patients in our study. This difference is probably due to the fact that their study included
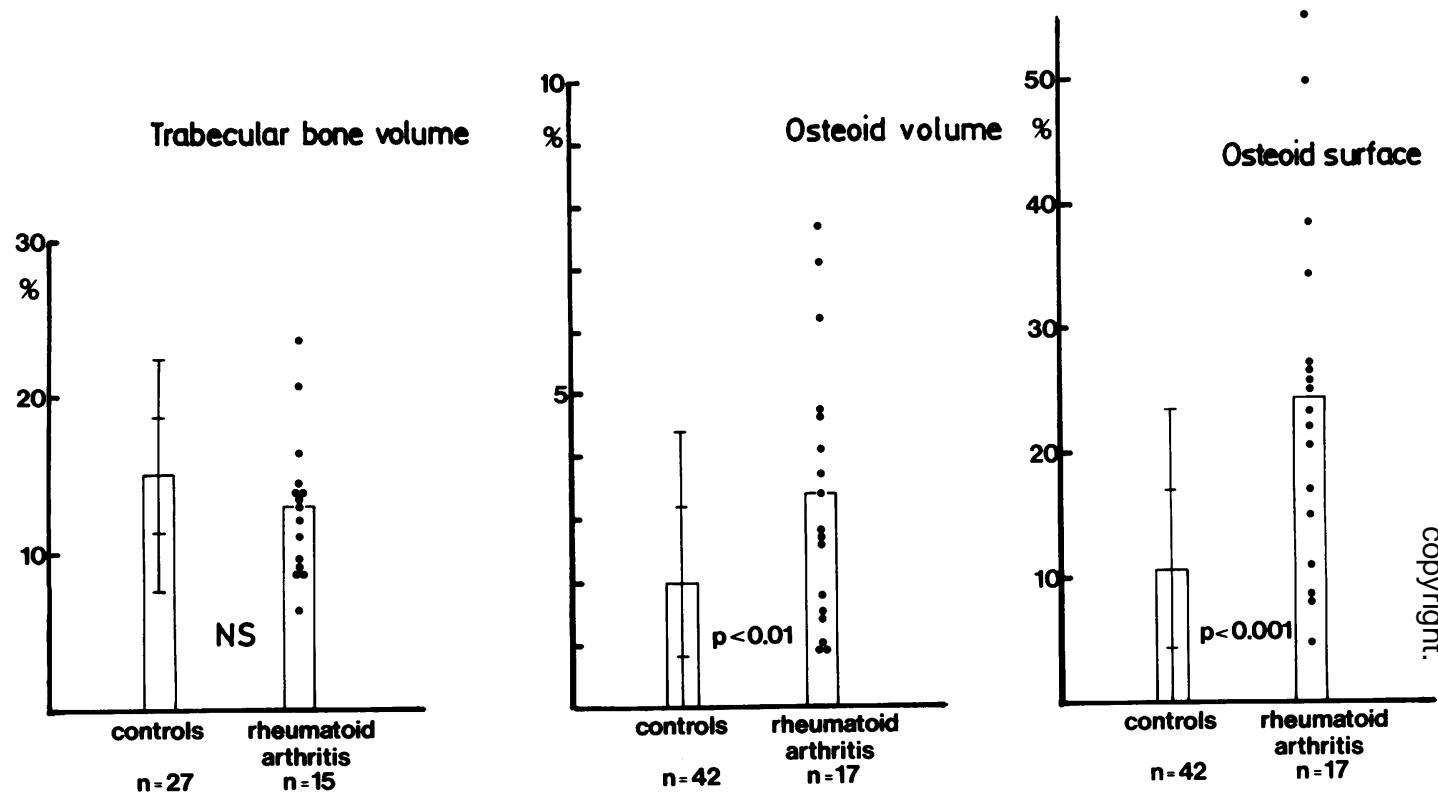

Thickness index of osteoid seams

Mineralisation rate
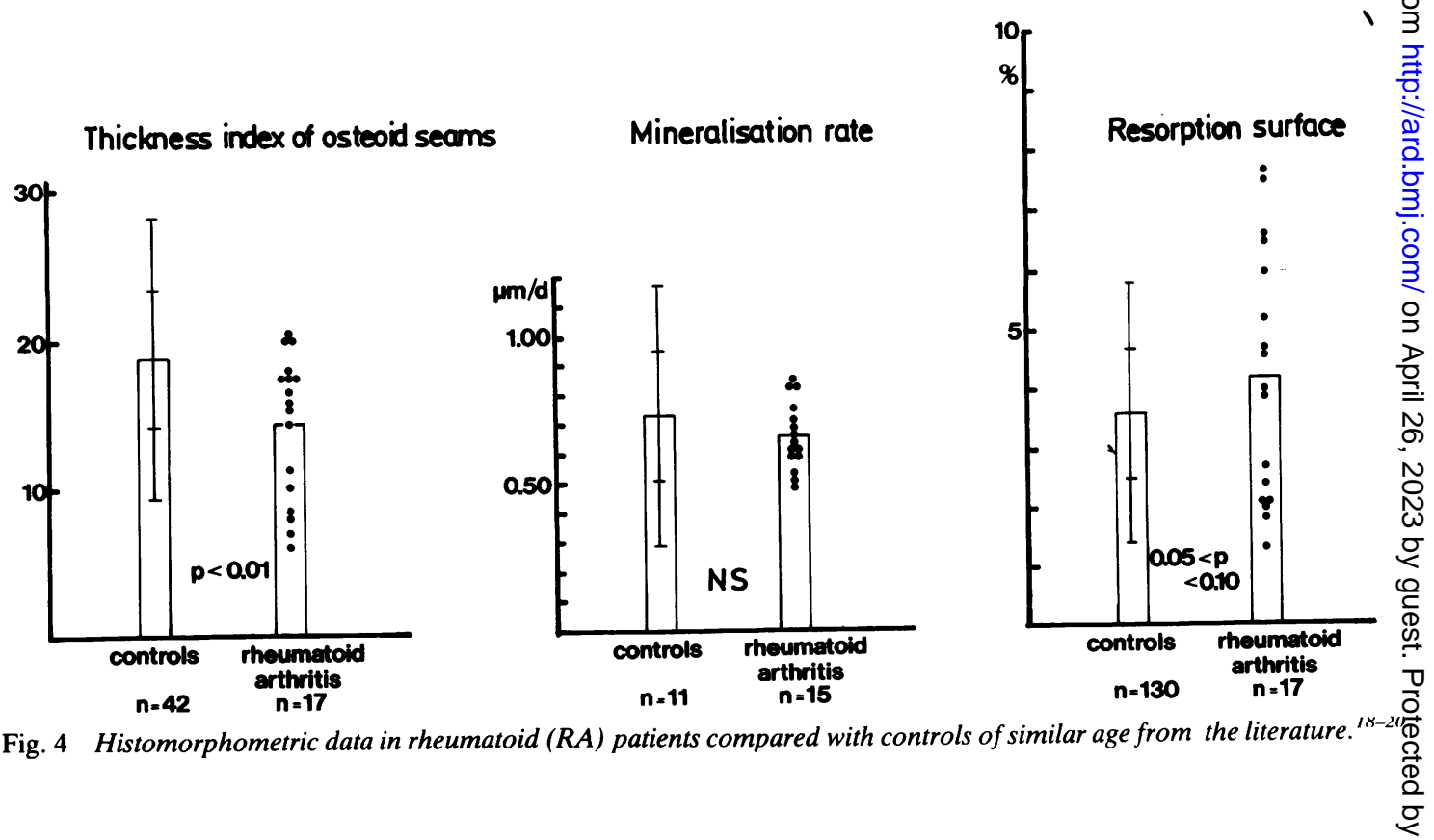

Fig. 4 Histomorphometric data in rheumatoid (RA) patients compared with controls of similar age from the literature. ${ }^{18-2}$ 
younger patients, whereas our patients were all over 50 years of age.

RA patients have a greater bone loss than osteoporotic patients, especially those taking corticosteroids. ${ }^{27}$ RA patients taking corticosteroids also have a greater bone loss than patients with bronchial asthma on corticosteroids, the bone loss occurring earlier in the course of the disease. ${ }^{19}$ Only six of the RA patients investigated had been taking or were on corticosteroids. No difference was found between them and the other RA patients with regards to calcium metabolism.

In conclusion our results indicate that in longstanding RA vitamin D deficiency accompanied by secondary hyperparathyroidism is an additional factor contributing to the severity of osteopenia. Circumstantial evidence suggests that disturbed turnover of $25(\mathrm{OH}) \mathrm{D}$ in the liver may have a role.

Questions remaining to be answered are whether this disturbance of calcium metabolism is dependent on the severity of the rheumatoid process and whether there is a contributing influence of NSAIDs on metabolism of vitamin $\mathrm{D}$ in the liver.

We are grateful to Mrs A Luyten-de Haas, dietician, Mrs J v d Pluym, Mr G J Postma, Mr A Bloot, Mr W Mairuhu, technicians, and Dr G Brutèl de la Riviere, pathologist for their help in carrying out this investigation.

\section{References}

1 Mueller M H, Jurist J M. Skeletal status in rheumatoid arthritis. A preliminary report. Arthritis Rheum 1973; 16: 66-70.

2 Kennedy A C, Smith D A, Buchanan W W, Anderson J B, Samuels B B, Jasani M K. Osteoporosis in rheumatoid arthritis 'R'. Rev Int Rhum 1974: 25-34.

3 Kennedy A C, Smith D A, Anton H C, Buchanan W W. Generalised and localised bone loss in patients with rheumatoid arthritis. Scand J Rheumatol 1975; 4: 209-15.

4 Kennedy A C. Smith D A, Buchanan W W, Anderson J B. Jasani M K. Bone loss in patients with rheumatoid arthritis. Scand J Rheumatol 1975; 4: 73-9.

5 Reid D M, Kennedy N S J, Tothill P, Smith M A, Nuki G. Total body calcium in rheumatoid arthritis: effects of disease activity and corticosteroid therapy. Heberden Society 1981: 44.

6 Madison P A, Bacon P A. Vitamin D deficiency, spontaneous fractures and osteopenia in rheumatoid arthritis. Br Med J 1974; iv: $433-5$.

7 O'Driscoll S, O'Driscoll M. Osteomalacia in rheumatoid arthritis. Ann Rheum Dis 1980; 39: 1-6.

8 Wordsworth B P, Vipond S, Woods C G, Mowat A G. Metabolic bone disease among patients with rheumatoid arthritis. $B r J$ Rheumatol 1984; 23: 251-7.
9 Walton R J, Bijvoet O L M. Nomogram for derivation of renal threshold phosphate concentration. Lancet 1975; ii: 309-10.

10 Payne R B, Little A J, Williams R B, Milner J R. Interpretations of serum calcium in patients with abnormal serum proteins. $\mathrm{Br}$ Med J 1973; iv: 643-6.

11 Jongen M J M, van der Vijgh W J F, Willems H J J, Netelenbos J C, Lips P. Simultaneous determination of 25 -hydroxy vitamin $\mathrm{D}, 24,25$-dihydroxy vitamin $\mathrm{D}$ and 1,25-dihydroxy vitamin $\mathrm{D}$ in plasma or serum. Clin Chem 1981; 27: 1751-60.

12 Mashige F, Tanaka N, Maki A, Kamei S, Yamanaka M. Direct spectrophotometry of total bile acids in serum. Clin Chem 1981; 27: $1352-62$.

13 Tobiasson P, Frydén A. Tagesson C. Serum bile acids after test meals and oral load of chenodeoxycholic acid. Scand $J$ Gastroenterol 1981; 16: 763-7.

14 Van den Ende A, Rädecker C E, Mairuhu W. Microanalysis of free and conjugated bile acids by thin-layer chromatography and in situ spectrofluorimetry. Anal Biochem 1983; 134: 153-62.

15 Richterich R, Colombo J P. Klinische Chemie, Theorie, Praxis, Interpretation. München: Karger, 1978: 460-4.

16 Marsh C A. Metabolism of D-glucuronolactone in mammalian systems. Biochem J 1963; 86: 77-86.

17 Lips P, Netelenbos J C, Jongen M J M, et al. Histomorphometric profile and vitamin D status in patients with femoral neck fractures. Metabolic Bone Dis Relat Res 1982; 4: 65-93.

18 Giroux J M, Courpron Ph, Meunier P J. Histomorphométrie de l'osteopénie physiologique sénile. Lab de recherches sur l'histodynamique osseuse. Lyon: Claude Bernard University Press, 1975.

19 Meunier P J, Edouard C, Richard D, Laurent J. Histomorphometry of osteoid tissue, the hyperosteoidoses. In: Meunier $P$ $\mathrm{J}$, ed. Second Int. Workshop on Bone Histomorphometry. Toulouse: Soc. de la Nouvelle Imprimerie Fournié. 1977; $249-62$.

20 Courpron $\mathrm{Ph}$. Données histologiques quantitatives sur le vieillisement osseux humain. Lyon, 1972. (Thesis.)

21 Eastwood J B. Philips M E. DeWardener H E. Effect of vitamin D (cholecalciferol) in anticonvulsant therapy. Metabolic Bone Dis Relat Res 1980; 2: 83-6.

22 Van Soesbergen R M. Lips P. Bone metabolism in rheumatoid arthritis (RA). Clin Rheumatol 1984; 3: 103.

23 Reid D M, Nicoll J, Brown N, et al. Corticosteroid induced bone loss in rheumatic diseases and bronchial asthma. Clin Rheumatol 1984; 3: 104.

24 Steven M M, Sturrock R D, Fogelman I, Smith M L. Skeletal metabolism in rheumatoid arthritis. Heberden Society 1981; 59.

25 Rajapakse C. Thompson R. Grennan D M. et al. Increased bone metabolism in rheumatoid arthritis as measured by the whole body retention of ${ }^{49 \mathrm{~m}} \mathrm{Tc}$ methylene diphosphonate. Ann Rheum Dis 1983; 42: 138-41.

26 Parfitt A M, Matthews C, Rao D. Frame B, Kleerkoper M. Villaneuva A R. Impaired osteoblast function in metabolic bone disease. In: de Luca H F. Frost H M, Lee W S S, Johnston C C. Parfitt A M. Osteoporosis: recent advances in pathogenesis and treatment. Baltimore: University Park Press, 1981: 321-30.

27 Ng K C, Revell P A, Beer M. Bouchier B J, Cohen R D, Currey $\mathrm{H}$ L F. Incidence of metabolic bone disease in rheumatoid arthritis and osteoarthritis. Ann Rheum Dis 1984; 43: 370-7. 